\title{
PTGS1 wt Allele
}

National Cancer Institute

\section{Source}

National Cancer Institute. PT GS1 wt Allele. NCI Thesaurus. Code C50904.

Human PT GS1 wild type allele is located within 9q32-q33.3 and is approximately $25 \mathrm{~kb}$ in length. This allele, which encodes prostaglandin $\mathrm{G} / \mathrm{H}$ synthase 1 protein, is involved in both tissue homeostasis and inflammation. 